\title{
Effects of live yeast culture addition into sucrose supplemented diet on fattening performance, some blood and histological parameters in Saanen male kids fed without forage
}

\author{
Kadir Emre BUGDAYCI ${ }^{1}$, Mustafa Numan OGUZ ${ }^{1}$, Fatma KARAKAS OGUZ ${ }^{1}$, \\ Metin Koray ALBAY ${ }^{2}$, Jale ONER ${ }^{3}$ \\ ${ }^{1}$ Mehmet Akif Ersoy University, Veterinary Faculty, ${ }^{1}$ Department of Animal Nutrition and Nutritional Diseases; ${ }^{2}$ Department of
Internal Medicine; ${ }^{3}$ Department of Histology and Embryology, Burdur, Turkey.
}

Summary: The aim of this study was to evaluate the effects of live yeast culture (LYC) as a feed additive on fattening performance, and some blood and rumen fluid parameters in male goats fed with sucrose (SU) supplemented diet. Totally 18 male Saanen goat kids were divided into three groups, no SU and no LYC (C) as control group, 3\% SU (S) and 3\% SU with LYC (S+LYC) as the treatment groups, each containing 6 kids. Diets of groups were formulated as isonitrojenic and isocaloric. LYC (Rumisacc, $344 \times 10^{10}$ cfu per gram) was included in the diet at $2 \%$ on feed basis. Feeding schema was established with no roughage, diets were given ad libitum, and the kids in each group were fed individually. In the experiment, ruminal ammonia- $\mathrm{N}$ increased and ruminal $\mathrm{pH}$ decreased in sucrose supplemented diet consumed groups $(\mathrm{p}<0.05)$ regardless of the supplementation of live yeast culture. Dietary sucrose with live yeast culture supplementation did not significantly affect fattening performance and blood parameters, except hemoglobin. Dorsal and ventral rumen papillae lengths were not affected by dietary treatments. Keratin layer of sucrose supplemented group $(S)$ was increased when compared with control group $(\mathrm{p}<0.05)$.

Keywords: Blood parameters, fattening performance, kid, live yeast culture, rumen parameters.

\section{Kaba yemsiz beslenen erkek Saanen oğlaklarının sukroz ilave edilmiş yemine canlı maya kültürü ilavesinin besi performansı, bazı kan ve histolojik parametreler üzerine etkileri}

Özet: $\mathrm{Bu}$ araştırmanın amacı sukroz (SU) ilavesi yapılan yemle beslenen keçilerde canlı maya kültürünün (LYC) besi performansı ile bazı kan ve rumen parametreleri üzerine etkisini incelemektir. Toplam 18 Saanen keçisi oğlağı; herbiri 6 oğlaktan oluşan SU ve LYC içermeyen kontrol grubu (C), \%3 SU içeren grup (S) ve \%3 SU ile LYC içeren grup (S+LYC) olmak üzere 3 gruba ayrılmıştır. Gruplara ait yemler isonitrojenik ve isokalorik olarak düzenlenmiştir. LYC (Rumisacc, $344 \times 10^{10} \mathrm{cfu} / \mathrm{g}$ ) yeme $\% 2$ düzeyinde ilave edilmiştir. Yemleme planı kaba yem içermeyecek şekilde düzenlenmiş, yem ad libitum verilmiştir, her bir gruptaki oğlaklar bireysel olarak beslenmiştir. Araştırmada canlı maya kültürü ilavesine bakılmaksızın sükroz ilave edilen yemi tüketen gruplarda ruminal amonyak azotu artmış ve rumen $\mathrm{pH}$ 'sı azalmıştır $(\mathrm{p}<0.05)$. Sükroz ile birlikte canlı maya kültürü ilavesi besi performansı ile hemoglobin dışında ki kan parametrelerini etkilememiştir. Rasyon uygulamaları dorsal ve ventral papilla uzunluklarını etkilememiştir. Sükroz ilave edilen grubun (S) keratin tabakası kontrol grubuna kıyasla artmıştır ( $\mathrm{p}<0.05)$.

Anahtar sözcükler: besi performansı, Canlı maya kültürü, kan parametreleri, oğlak, rumen parametreleri.

\section{Introduction}

It is well known that young animals fed with high concentrate diets generally have better performance and carcass quality than animals fed in a forage system (19). Mandebvu1 and Galbraith (21) replaced barley with sugar beet pulp in the diets of lambs at different proportions and stated that high amounts of dietary barley increased hot and cold carcass weights without changing ruminal $\mathrm{pH}$. Besides Papia et al. (27) reported that, the increase of concentrate feed level in diet (up to $700 \mathrm{~g} / \mathrm{kg}$ ) improves growth rate, feed efficiency and dressing percentage in lambs but the amount of $900 \mathrm{~g} / \mathrm{kg}$ concentrate feed in the diet decreased average daily gain and final body weight. This result may be caused by rumen acidosis. Excessive intake of rapidly fermentable carbohydrates is one of the causes of ruminal acidosis. Ruminal papillae increase in length when cattle are fed with higher grain diets; this presumably increases the surface area and absorptive capacity, which protects the animal from acid accumulation in the rumen (25).

Yeast and yeast products have been used in ruminant nutrition to manipulate rumen fermentation and improve animal performance. Chaucheyras-Durand et al. (6) mentioned that active dried yeast have positive effects on rumen microbial activity in young ruminants, stabilisation of rumen $\mathrm{pH}$ and prevention of acidosis, as 
well as stimulation of growth activity of fiber degrading bacteria. The effects of yeast supplementation on volatile fatty acid (VFA) concentration has conflicting results on dairy cattles $(8,9)$ and goats $(26)$. These differences may depend on many factors such as diet composition, forage to concentrate ratio, type of forage feed, yeast dose, feeding strategy and stage of lactation (31).

For many years, scientists have shown greater interests in manipulating the microbial ecosystem of the rumen to improve production efficiency by domestic ruminants. The benefits of live yeast culture are well understood; however, researches in kids and lambs are limited.

Recent investigations indicated that addition of Saccharomyces cerevisiae live yeast cultures has improved live weight gain $(18,26)$ and dry matter intake in goats (18), and feed efficiency in lambs (16). Saccharomyces cerevisiae live yeast cultures has also increased ruminal $\mathrm{pH}$ in goats $(1,26)$.

Feeding kids with grain based diet can provide simply their nutritional needs for growth however supplements such as buffers may be needed to avoid ruminal sickness. Yeast and yeast products as a feed additive may be stabilize rumen $\mathrm{pH}$ and prevent acidosis in this circumstance. Male Saanen kids are generally fed with forages by the families and slaughtered without getting economic value in Turkey.

Effects of supplementing live yeast culture into diets of fattening Saanen kids have not been studied. The objective of this study was to determine the effects of live yeast culture supplementation to sucrose added diets on feed intake, growth performance and some blood parameters in male Saanen kids. The aim of sucrose supplementation to diet was to support live yeast culture and their activity in rumen. Sucrose is one of the most widely used energy source for yeast growth.

\section{Material and methods}

The experiment was conducted in a commercial farm in Burdur, Turkey. Management protocols, animal care and protocols of the research were made in accordance with approved local ethical committee on animal experiments of Mehmet Akif Ersoy University (01.04.2013-93773921-31- verdict no: 30).

A total of 18 male Saanen kids aged 1 month were used at the study. All the animals were treated for internal and external parasites using Ivomec (Novakim; active ingredient: $10 \mathrm{mg} / \mathrm{ml}$ Ivermectin; dose: $1 \mathrm{ml} / 50 \mathrm{~kg}$ live weight) 2 weeks before the experiment started. This study was conducted at the commercial feedlot from

Table 1: The ingredients and chemical composition of experimental diets.

Tablo 1: Deneme yemlerinin içeriği ve kimyasal bileşimi.

\begin{tabular}{|c|c|c|c|}
\hline \multirow{2}{*}{ Ingredients, $\%$ on feed basis } & \multicolumn{3}{|c|}{ Dietary treatments } \\
\hline & $\mathrm{C}$ & $S$ & $\mathrm{~S}+\mathrm{LYC}$ \\
\hline Corn & 34 & 30 & 30 \\
\hline Barley & 24 & 24 & 24 \\
\hline Wheat Bran & 9 & 9 & 9 \\
\hline Full fat soy & 15 & 15 & 15 \\
\hline Sunflower meal & 6 & 6 & 6 \\
\hline Soybean meal & 5 & 6 & 4 \\
\hline DCP & 2 & 2 & 2 \\
\hline Canola oil & 3 & 3 & 3 \\
\hline DL-methionine & 0.2 & 0.2 & 0.2 \\
\hline L-Lysine hydrochloride & 0.2 & 0.2 & 0.2 \\
\hline Sucrose & - & 3 & 3 \\
\hline Live yeast culture $^{1}$ & - & - & 2 \\
\hline Lime stone & 1 & 1 & 1 \\
\hline Salt & 0.4 & 0.4 & 0.4 \\
\hline Vitamin mineral premix ${ }^{2}$ & 0.2 & 0.2 & 0.2 \\
\hline \multicolumn{4}{|c|}{ Analyzed chemical composition on fed basis } \\
\hline Dry matter, $\%$ & 91.77 & 92.15 & 92.27 \\
\hline Crude protein, $\%$ & 15.40 & 15.11 & 15.35 \\
\hline Ether extract, \% & 5.70 & 5.44 & 5.81 \\
\hline $\mathrm{ME}, \mathrm{kcal} / \mathrm{kg} \mathrm{ME}$ & 2806.19 & 2794.70 & 2830.03 \\
\hline
\end{tabular}

C: Control group; S: Group fed with sucrose supplemented concentrate; S + LYC: Group fed with sucrose and live yeast culture supplemented concentrate; 1: RumiSacc, Integro Food Industry and Trade Co., İstanbul, Turkey; 2: Each kilogram of vitaminmineral mix contains $12000000 \mathrm{IU}$ A vit, $20000 \mathrm{mg}$ E vit, $50000 \mathrm{mg} \mathrm{Mn,} 50000 \mathrm{mg} \mathrm{Fe}, 50000 \mathrm{mg} \mathrm{Zn}, 10000 \mathrm{mg} \mathrm{Cu}, 800 \mathrm{mg} \mathrm{I}$, $150 \mathrm{mg} \mathrm{Co}, 150 \mathrm{mg} \mathrm{Se}$

C: Kontrol grubu; S: Sükroz ilave edilen yem ile beslenen grup; S+LYC: Sükroz ve canlı maya kültürü ilave edilen yem ile beslenen grup; 1: RumiSacc, İntegro gıda sanayi ve ticaret A.Ş., İstanbul, Türkiye; 2: Vitamin-mineral premiksi karma yemin her kg'da 12 $000000 \mathrm{IU}$ A vit, $20000 \mathrm{mg}$ E vit, $50000 \mathrm{mg} \mathrm{Mn,} 50000 \mathrm{mg} \mathrm{Fe}, 50000 \mathrm{mg}$ Zn, $10000 \mathrm{mg} \mathrm{Cu}, 800 \mathrm{mg} \mathrm{I}, 150 \mathrm{mg} \mathrm{Co,} 150 \mathrm{mg} \mathrm{Se}$ içermektedir. 
April 2013 to August 2013. All kids were housed in individual cages $(100 \times 150 \times 120 \mathrm{~cm})$ under the shed with concrete floor with sawdust and dried manure as bedding material for the entire period of the experiment. The cages were separated by partitions not allowing the kids to have a close contact with one another. Saanen kids were divided into three groups, no $\mathrm{S}$ and no LYC as the control (C) group, $3 \% \mathrm{SU}(\mathrm{S})$, and $3 \% \mathrm{SU}$ with LYC $(\mathrm{S}+\mathrm{LYC})$ as the treatment groups, each containing 6 kids. Diets were prepared as mash feed. LYC (Rumisacc, 344 $\mathrm{x} 10^{8}$ cfu per gram) was included in the diet at $2 \%$ on feed basis. Feeding schema was established with no roughage, diets were given ad libitum. The ingredients and the chemical composition of the diets are presented in Table 1.

During the study, water and diets were given ad libitum. No forage was used in the formulation of group rations. Nutrient composition of diets and live yeast culture product were determined according to the AOAC (2). The metabolizable energy levels of diets were determined by using the following formula of TSI (29).

$\mathrm{ME}(\mathrm{kcal} / \mathrm{kg} \mathrm{OM})=3260+(0.455 \mathrm{xCP})-$ $(4.037 \mathrm{xCF})+(3.517 \mathrm{xEE})$ where $\mathrm{CP}$ (crude protein), $\mathrm{CF}$ (crude fibre) and $\mathrm{EE}$ (ether extract) were expressed as $\mathrm{g} / \mathrm{kg} \mathrm{OM}$ (organic matter) and converted dry matter (DM) basis.

Animals were individually weighed at the beginning of the experiment and every two weeks. The average daily weight gain over the duration of experiment was determined individually. Feed consumption of each kid were measured weekly as the difference between the amount offered and residues. Feed conversion ratio was calculated as $\mathrm{kg}$ feed per $\mathrm{kg}$ live weight gain of kids individually.

The kids were sacrificed by exsanguination in a commercial slaughter house. Ruminal fluid and rumen wall samples of each animal were collected during the slaughtering process.

Carcasses were weighed, suspended through the Achilles tendon, and then chilled at $4^{\circ} \mathrm{C}$ for $24 \mathrm{~h}$. By this method, hot and cold carcass yield were determined.

Rumen fluid samples were collected in laboratory sample containers $(2 \times 100 \mathrm{ml})$ from all kids in each group during the slaughtering process. The $\mathrm{pH}$ was measured immediately by a $\mathrm{pH}$ meter (Hanna $\mathrm{pH}$ meter, model no: $\mathrm{Hi} 917 \mathrm{hN}$ ) in the sample.

Blood samples were taken in two tubes from jugular vein containing EDTA for hematological analysis and without EDTA for biochemical analysis at the last day of the experiment. Tubes for biochemical analysis were centrifuged at 3,000 rpm at room temperature for 5 minutes, and then serum was carefully harvested for determination of total cholesterol, triglyceride, glucose and blood urea nitrogen (BUN) were analyzed by VET TEST 8008 Autoanalyzer (IDEXX Laboratories, inc
Westbrook ME 04092 USA). Other blood samples for hematological analysis were freshly analyzed by Abacus Junior Vet Hemmatology Analyzer (Diatron MI PLC. Hungary).

Samples for histological and morphometric examination were collected from the bottom of saccus ruminis ventralis and dorsalis after the slaughter of the animals. The size of the samples was approximately $1 \times 1 \times 0.5 \mathrm{~cm}$. The tissues were fixed for a period of $72 \mathrm{~h}$ after the collection in $10 \%$ formalin. Afterwards, the samples were processed using the common paraffin method, stained with haemotoxylin-eosin, and evaluated by a light microscope. Ten papillae were measured in each section: the length of the papilla (from the base to the apex), the width of the epithelium (the distance between the external border of lamina propria mucosae and internal border of stratum corneum at the papillar base), the width of stratum corneum from the external end of stratum lucidum to the papillary surface and also keratinisation on the surface of the papillae.

The statistical analysis was done using SPSS programme (SPSS Inc., Chicago, IL, USA). The normality of data distribution was checked using Shapiro-Wilk test. One way ANOVA was performed to detect the differences among groups. The significance of mean differences between groups was tested by Duncan (7). Values were given as mean \pm standard error. Level of significance was taken as $\mathrm{p}<0.05$.

\section{Results}

The crude protein analysis showed that live yeast is rich in protein $(44.31 \%)$. The analysis also illustrated that dry matter, crude ash, eter extract and crude fibre ingredients were $93.45 \% ; 11.65 \% ; 3.89 \%$ and $3.07 \%$ respectively. Dietary live yeast supplementation did not significantly affect live weight (Table 2), feed intake (Table 3) and live weight gain (Table 4) of kids during the study.

Live yeast culture did not affect hot and cold carcass yield (Table 4) when compared with the other groups. In the present study, ruminal $\mathrm{pH}$ of sucrose supplemented groups ( $\mathrm{S}$ and $\mathrm{S}+\mathrm{LYC}$ ) were affected negatively $(\mathrm{p}<0.05)$. Besides, ruminal ammonia-N concentration of both sucrose supplemented groups ( $\mathrm{S}$ and $\mathrm{S}+\mathrm{LYC})$ were significantly higher $(\mathrm{p}<0.05)$ than unsupplemented $\mathrm{C}$ group (Table 5). Blood chemistry results (Table 6) of total cholesterol, glucose, triglyceride, BUN and some hematologycal parameters did not change except HGB and HCT by dietary live yeast culture supplementation. HGB levels of treatment groups ( $\mathrm{S}$ and $\mathrm{S}+\mathrm{LYC}$ ) were significantly $(\mathrm{p}<0.05)$ decreased when compared with control group. HCT levels of S + LYC group was similar with control group however HCT levels of $\mathrm{S}$ group was significantly $(\mathrm{p}<0.05)$ decreased. 
Table 2. Effects of dietary treatments on body weight (BW),g.

Tablo 2. Rasyon uygulamalarının canlı ağırlık üzerine etkileri (CA),g.

\begin{tabular}{lcccc}
\hline & \multicolumn{3}{c}{ Dietary treatments } & $\mathrm{p}$ \\
\cline { 2 - 4 } & $\mathrm{C}$ & $\mathrm{S}$ & $\mathrm{S}+\mathrm{LYC}$ & 0.622 \\
Initial BW & $8850 \pm 681$ & $9241 \pm 652$ & $9790 \pm 620$ & 0.578 \\
Day 14 & $10416 \pm 817$ & $10933 \pm 633$ & $11520 \pm 659$ & 0.876 \\
Day 28 & $12800 \pm 978$ & $13391 \pm 934$ & $13330 \pm 720$ & 0.951 \\
Day 42 & $15025 \pm 921$ & $15341 \pm 1164$ & $14930 \pm 589$ & 0.757 \\
Day 56 & $17658 \pm 1049$ & $17141 \pm 1240$ & $16530 \pm 568$ & 0.514 \\
Day 70 & $19800 \pm 1241$ & $18175 \pm 1461$ & $17790 \pm 465$ & 0.283 \\
Day 84 & $23366 \pm 1345$ & $20416 \pm 1889$ & $20320 \pm 865$ & 0.264 \\
Day 98 & $26058 \pm 1834$ & $22175 \pm 1982$ & $23670 \pm 1272$ & 0.304 \\
Day 112 & $25816 \pm 1483$ & $22400 \pm 2012$ & $25060 \pm 968$ & 0.749 \\
Day 119 & $25841 \pm 1443$ & $24458 \pm 2304$ & $26280 \pm 1022$ & 0 \\
\hline
\end{tabular}

$\mathrm{n}=6, \mathrm{p}<0.05$

Table 3. Effects of dietary treatments on feed intake, $\mathrm{g} / \mathrm{d}$.

Tablo 3. Rasyon uygulamalarının yem tüketimi üzerine etkileri, g/d.

\begin{tabular}{lcccc}
\hline & \multicolumn{3}{c}{ Dietary teratment } & $\mathrm{p}$ \\
\cline { 2 - 4 } & $\mathrm{C}$ & $\mathrm{S}$ & $\mathrm{S}+\mathrm{LYC}$ & 0.177 \\
Day 1-42 & $518 \pm 45$ & $626 \pm 45$ & $544 \pm 21$ & 0.112 \\
Day 43-84 & $833 \pm 55$ & $698 \pm 51$ & $696 \pm 33$ & 0,853 \\
Day 85-119 & $906 \pm 62$ & $918 \pm 58$ & $951 \pm 31$ & \\
\hline
\end{tabular}

$\mathrm{n}=6, \mathrm{p}<0.05$

Table 4. Effects of dietary treatments on performance parameters, hot and cold carcass weights and yields.

Tablo 4.Deneme süresince rasyon uygulamalarının performans parametreleri, sıcak ve soğuk karkas randımanı ve ağırlığı üzerine etkileri.

\begin{tabular}{lcccc}
\hline & \multicolumn{3}{c}{ Dietary treatments } & $\mathrm{p}$ \\
\cline { 2 - 4 } & $\mathrm{C}$ & $\mathrm{S}$ & $\mathrm{S}+\mathrm{LYC}$ & 0.694 \\
\hline Weight gain, g/d & $142.78 \pm 11.13$ & $127.87 \pm 16.25$ & $138.57 \pm 8.63$ & 0.766 \\
Feed intake, g/d & $753.76 \pm 37.77$ & $735.72 \pm 41.97$ & $714.09 \pm 27.50$ & 0.249 \\
Feed conversion ratio, (kg feed & $5.33 \pm 0.19$ & $6.07 \pm 0.55$ & $5.20 \pm 0.55$ & \\
intake / kg weight gain) & & & & 0.512 \\
Hot carcass weight, kg & $12.26 \pm 0.72$ & $10.93 \pm 1.26$ & $12.28 \pm 0.54$ & 0.447 \\
Cold carcass weight, kg & $12.03 \pm 0.72$ & $10.63 \pm 1.24$ & $12.16 \pm 0.54$ & 0.102 \\
Hot carcass yield, \% & $47.44 \pm 0.62$ & $44.28 \pm 1.13$ & $46.76 \pm 1.31$ & 0.060 \\
Cold carcass yield, \% & $46.53 \pm 0.71$ & $43.04 \pm 1.21$ & $46.30 \pm 1.23$ & \\
\hline
\end{tabular}

$\mathrm{n}=6, \mathrm{p}<0,05$

Table 5. Effects of dietary treatments on rumen $\mathrm{pH}$ and rumen $-\mathrm{NH}_{3}-\mathrm{N}$

Tablo 5. Rasyon uygulamalarının rumen $\mathrm{pH}$ 'si ve rumen $-\mathrm{NH}_{3}-\mathrm{N}$ ' si üzerine etkileri

\begin{tabular}{lcrrr}
\hline & \multicolumn{3}{c}{ Dietary treatments } & $\mathrm{p}$ \\
\cline { 2 - 4 } & $\mathrm{C}$ & $\mathrm{S}$ & $\mathrm{S}+\mathrm{LYC}$ & 0.021 \\
Rumen $\mathrm{pH}$ & $6.35 \pm 0.20^{\mathrm{a}}$ & $5.79 \pm 0.07^{\mathrm{b}}$ & $5.70 \pm 0.15^{\mathrm{b}}$ & \\
Rumen $\mathrm{NH}_{3}-\mathrm{N}, \mathrm{mg} / \mathrm{l}$ & $686.56 \pm 105.06^{\mathrm{b}}$ & $1134.56 \pm 94.21^{\mathrm{a}}$ & $1143.85 \pm 77.33^{\mathrm{a}}$ & 0.004 \\
\hline
\end{tabular}

$\mathrm{n}=6, \mathrm{p}<0.05$ 
Table 6. Final hematological and blood chemistry results of kids.

Tablo 6. Oğlaklara ait araştırma sonu hematoloji ve kan kimyası sonuçları.

\begin{tabular}{lcccc}
\hline & \multicolumn{3}{c}{ Dietary teratment } & p \\
\cline { 2 - 3 } & & $\mathrm{C}$ & $\mathrm{S}+\mathrm{LYC}$ & \\
\hline Fresh blood parameters & $12.73 \pm 2.88$ & $10.90 \pm 1.02$ & $11.25 \pm 1.07$ & 0.777 \\
WBC, $10^{9} / \mathrm{L}$ & $18.65 \pm 0.57$ & $17.20 \pm 0.57$ & $17.40 \pm 0.70$ & 0.217 \\
RBC, $10^{12} / \mathrm{L}$ & $10.60 \pm 0.37^{\mathrm{a}}$ & $9.03 \pm 0.28^{\mathrm{b}}$ & $9.34 \pm 0.52^{\mathrm{b}}$ & 0.027 \\
HGB, g/dl & $27.57 \pm 0.71^{\mathrm{a}}$ & $24.10 \pm 0.79^{\mathrm{b}}$ & $25.35 \pm 1.12^{\mathrm{ab}}$ & 0.034 \\
HCT, \% & $14.66 \pm 0.42$ & $14.16 \pm 0.47$ & $14.80 \pm 0.58$ & 0.636 \\
MCV, fl & $5.68 \pm 0.08$ & $5.25 \pm 0.11$ & $5.36 \pm 0.19$ & 0.083 \\
MCH, Pg & $38.41 \pm 0.65$ & $37.58 \pm 0.91$ & $37.09 \pm 1.01$ & 0.565 \\
MCHC, g/dl & $44.80 \pm 1.28$ & $45.40 \pm 0.79$ & $44.60 \pm 1.08$ & 0.863 \\
RDWc, \% & & & \\
Blood serum parameters & $3.11 \pm 0.41$ & $2.52 \pm 0.28$ & $2.05 \pm 0.12$ & 0.104 \\
Total cholesterol, mmol/L & $4.02 \pm 0.32$ & $4.45 \pm 0.24$ & $4.08 \pm 0.23$ & 0.496 \\
Glucose, mmol/L & $6.66 \pm 0.49$ & $7.96 \pm 0.68$ & $6.80 \pm 0.34$ & 0.207 \\
BUN, mmol/L & $0.38 \pm 0.06$ & $0.29 \pm 0.02$ & $0.26 \pm 0.03$ & 0.222 \\
Triglyceride, mmol/L & & & & \\
\hline $\mathrm{n}=6, \mathrm{p}<0.05$ & & & \\
\end{tabular}

$\mathrm{n}=6, \mathrm{p}<0.05$

Table 7. Effects of dietary treatments on the length of rumen papillae with the thickness of papillae epithelium and keratin, $\mu \mathrm{m}$. Tablo 7. Rasyon uygulamalarının rumen papilla uzunluğu ile papilla epiteli ve keratin kalınlığı üzerine etkileri, $\mu \mathrm{m}$.

\begin{tabular}{|c|c|c|c|c|}
\hline & \multicolumn{3}{|c|}{ Dietary treatments } & \multirow[b]{2}{*}{$\mathrm{p}$} \\
\hline & $\mathrm{C}$ & $S$ & $S+L Y C$ & \\
\hline Dorsal papillae & $\begin{array}{c}2610.41 \pm 287.74 \\
(\mathrm{n}=6)\end{array}$ & $\begin{array}{c}2434.58 \pm 131.20 \\
(\mathrm{n}=6)\end{array}$ & $\begin{array}{c}2124.90 \pm 174.71 \\
(\mathrm{n}=5)\end{array}$ & 0.314 \\
\hline Ventral papillae & $\begin{array}{c}2027.50 \pm 143.63 \\
(\mathrm{n}=5)\end{array}$ & $\begin{array}{c}2217.50 \pm 243.83 \\
(n=4)\end{array}$ & $\begin{array}{c}2462.50 \pm 143.16 \\
(n=4)\end{array}$ & 0.263 \\
\hline Epithel & $\begin{array}{c}64.67 \pm 3.95 \\
(\mathrm{n}=6)\end{array}$ & $\begin{array}{c}70.88 \pm 5.70 \\
(\mathrm{n}=6)\end{array}$ & $\begin{array}{c}58.63 \pm 1.17 \\
(\mathrm{n}=6)\end{array}$ & 0.138 \\
\hline Keratin & $\begin{array}{c}22.21 \pm 3.37^{\mathrm{b}} \\
(\mathrm{n}=6)\end{array}$ & $\begin{array}{c}54.22 \pm 12.14^{\mathrm{a}} \\
(\mathrm{n}=6)\end{array}$ & $\begin{array}{c}24.00 \pm 1.15^{\mathrm{b}} \\
(\mathrm{n}=6)\end{array}$ & 0.001 \\
\hline
\end{tabular}

$\mathrm{p}<0.05$

Effects of dietary treatments on rumen papillae morphology were presented in Table 7. Dorsal and ventral papilla lengths were not affected by dietary treatments. Thickness of keratin layer of $\mathrm{S}$ group was higher than $\mathrm{C}$ group ( $<<0.05)$, however keratin layer of $\mathrm{S}$ + LYC group had no significance when compared with $\mathrm{C}$ group.

\section{Discussion and Conclusion}

Dietary treatments of all groups did not significantly affect live weight gain of kids. However, some researchers found that dietary live yeast increased live weight gain of goats $(18,26)$ and lambs $(16)$. There are also several studies which have mentioned improvement in feed conversion ratio due to yeast feeding in lambs (16) and in goats (17). However, Titi et al. (28) reported that yeast culture supplementation increased digestibility with no effect on growth, feed intake or feed conversion ratio of fattening Awassi lambs and Shami kids. Kawas et al. (19) studied the effects of live yeast culture on the feed intake of lambs fed with only concentrate ( $17 \%$ crude protein). Researchers reported that there are no beneficial effects on feed intake of lambs, which overlaps the findings of the present study. They declared that yeast culture did not affect feed intake due to the high protein level which originates from an inverse proportion with the proportion of protein level and yeast culture in diet.

There is a few references available concerning effects of yeast culture supplementation on carcass yield parameters in kids. Hot and cold carcass yield parameters are similar with Titi et al. (28) which reported that yeast culture supplementation did not affect cold dressing proportion and hot carcass weight of Shami goat kids. In 
lambs, Kawas et al (19) reported that yeast culture supplementation had no effect on hot and chilled carcass weights with the same as our results. The reason for this similarity in carcass yield parameters could be due to similar live weight gain of treatment groups. Live yeast supplementation did not affect ruminal $\mathrm{pH}$ of $\mathrm{S}+\mathrm{LYC}$ group when compared with $\mathrm{S}$ group. Studies that have examined effects of yeast cultures on ruminal $\mathrm{pH}$ have yielded variable result. Several of these studies have reported significant increases on ruminal $\mathrm{pH}$ in goats $(1$, 26). In contrast, some other studies found that ruminal $\mathrm{pH}$ was not affected by the supplementation of Saccharomyces cerevisia $(13,15,18)$. This difference may be attributed to composition of the rations and strain of the yeast culture. In the present study, kids were adapted to sucrose supplemented diet in an early age, this situation may have kept the level of $\mathrm{pH}$ at the range of 5.50 to 6.00 in sucrose supplemented $\mathrm{S}$ and $\mathrm{S}+\mathrm{LYC}$ groups. However, dietary sucrose supplementation generally decreased ruminal $\mathrm{pH}$ when compared with the control group regardless of dietary live yeast supplementation.

Aydin et al. (3) and Moya et al. (24) reported that dietary yeast culture supplementation did not affect ruminal ammonia-N concentration on sheep and heifers respectively. However, results of present study is similar to several studies which reported that ruminal ammonia$\mathrm{N}$ concentrations were significantly increased by dietary yeast culture supplementation on goats (28) and on rams (14). Live yeast culture supplementation in both low and high ratio of forage/concentrate diets significantly increased ruminal ammonia-N (13). Researchers attributed this result to increment of proteolysis and of protein deamination by microorganisms in rumen. The present study claims that the potential of greater microbial protein production in rumen may increase ruminal ammonia-N concentration in kids. On the other side, dietary sucrose supplementation generally increased ruminal ammonia-N concentration when compared with the control group regardless of dietary live yeast supplementation.

In the present study plasma cholesterol and triglyceride concentrations of kids were not altered by live yeast supplementation at the end of the experiment. Similar results were obtained by some other researchers in goats (28) and in dairy cows (31). On the contrary, Galip (14) reported that dietary yeast culture did not change cholesterol, decreased triglyceride and increased blood urea nitrogen in rams. Blood urea nitrogen concentration was not changed by dietary yeast supplementation in the study. This may be caused by the conversion potency of degraded protein to microbial protein in rumen.

Supplementation of yeast culture in diets of ruminants had different results on blood HGB and HCT levels. Galip (14) were reported HGB and HCT were not affected by dietary yeast culture in rams, however Milewski and Sobiech (22) indicated that dietary dry yeast supplementation was increased HGB and HCT levels in ewes. The HGB values of goats vary between 8 and $12 \mathrm{~g} / \mathrm{dL}$ (10, 30). Similarly Aytuğ (4) reported that avarage hemoglobin level for goats was $10.0 \mathrm{gr} / \mathrm{dL}$. In our study HGB concentration of control (C) and treatment groups (S and S+LYC) were 10.60, 9.03 and $9.34 \mathrm{~g} / \mathrm{dl}$ respectively. HGB values of all groups were in the range of normal levels. However hemoglobin levels of treatment groups were lower $(p<0.05)$ than control group, this difference may be caused by dietary sucrose supplementation and health status of kids.

Aytuğ (4) reported the variation limits for HCT values of goats were 34 and $48 \%$, averaging $35 \%$. A more recent report declares the limits for hematocrit values of goats were 22 and $38 \%$ (30). In our study HCT concentration of control and treatment groups ( $\mathrm{S}$ and S+LYC) were 27.57, 24.10 and $25.35 \%$ respectively. In the present study HCT values all groups were in the range of normal levels. A study on Honamli goat reported that HCT values of kids were $26.3 \%$ and goats were $22.1 \%$. Researchers decelerated that this could be characteristic for this breed however less nutrient supply from roughage could affect hematocrit values (11). In the study HCT levels of $S$ group was degreased $(p<0,05)$ however S + LYC group has no significance when compared with control group. This could be caused by probiotic activity of live yeast culture.

Various studies are available regarding the effect of nutrition on rumen papillae size. The papillae size is directly related to food intake, digesta weight in rumen, rate of fermentation, and weight of rumen. The diet influences rumen papillae surface area, and eventually the rumen efficiency and animal health (23). Butyrate has been shown to have potent effects on papillae size (23, 13). To our knowledge, this is the first report regarding the effect of live yeast culture addition to sucrose supplemented diet on rumen papillae morphology in paraffin sections. The results presented in this paper showed that ventral and dorsal papillae lengths of all groups were similar. Interestingly, while dorsal and ventral papilla lengths of $\mathrm{S}$ group did not change when compared with $\mathrm{C}$ group, keratin layer thicknesses of $\mathrm{S}$ group were much more than the other groups.

It is concluded that addition of live yeast culture at the level of $2 \%$ to sucrose $(3 \%)$ supplemented diet did not affect fattening performance and some blood parameters of male Saanen kids when compared with sucrose supplemented group (S) and the control group (C) which was not supplemented with sucrose. In the experiment, ruminal ammonia- $\mathrm{N}$ increased and ruminal $\mathrm{pH}$ decreased in sucrose supplemented diet consumed groups regardless of the supplementation of live yeast 
culture. When sucrose supplemented groups are compared with each other, it is seen that keratin thickness of rumen was decreased by live yeast supplementation.

The differences between some previous studies and the results of present study may be due to diet composition, environmental conditions, type of yeast feeding and strain and dose of yeast culture.

\section{Acknowledgements}

This work was supported by Integro Food and Feed Manufacturing (İstanbul / Turkey).

\section{References}

1. Abd El-Ghani AA (2004): Influence of diet supplementation with yeast culture (Saccharomyces cerevisiae) on performance of Zaraibi goats. Small Rumin Res, 52, 223-229.

2. AOAC (2000): Official Methods of Analysis. 17th ed. Association of Official Analytical Chemists. AOAC International, Maryland.

3. Aydın C, Galip N, Yaman K, Cengiz F, Türkmen İ, Biricik H (2003): Effect of Saccharomyces cerevisiae live yeast culture on ruminal metabolites and protozoa in Klvirclk male yearlings fed high forage and concentrate diet. Turk J Vet Anim Sci, 26, 1433-1440.

4. Aytuğ, CN (1990): Fizyolojik veriler. 523-537. In: CN Aytuğ, E Alacam, Ü Özkoç, BC Yalçın, H Türker, H Gökçen (Ed), Koyun-Keçi Hastalıkları ve Yetiştiriciliği. TUM VET. Hayvancılık Hizmetleri Yayını. No:2

5. Cernik J, Stercova E, Sterc J, Fictum P, Lunacek J, Halouzka R (2011): The effect of intensive fattening of bulls with a high-concentrate diet on ruminal mucosa-a morphometric study. Acta Vet Brno, 80, 275-279.

6. Chaucheyras-Durand F, Walker ND, Bach A (2008): Effects of active dry yeasts on the rumen microbial ecosystem: Past, present and future. Anim Feed Sci Tech, 145, 5-26.

7. Dawson B, Trapp RG, (2001): Basic and Clinical Biostatistics, third ed. Lange Medical Books/McGraw-Hill Medical Publishing Division, New York. 161-182.

8. Desnoyers M, Giger-Reverdin S, Bertin G, DuvauxPonter C, Sauvant D, (2009): Meta-analysis of the influence of Saccharomyces cerevisiae supplementation on ruminal parameters and milk production of ruminants. $\mathrm{J}$ Dairy Sci, 92, 1620-1632.

9. Dolezal P, Dolezal J, Trinacty J (2005): The effect of Saccharomyces cerevisiaeon ruminal fermentation in dairy cows. Czech J Anim Sci, 50, 503-510.

10. Dukes, HH (2003): Duke's Veterinary Physiology, 12th ed. (Cornell University Press, Ithaca).

11. Elmaz Ö, Saatcı M, Dağ B, Aktaş AH, Ata A, Gülay MŞ, Mamak N, Gök B. (2012): Some descriptive characteristics of a new goat breed called Honamli in Turkey. Trop Anim Health Prod, 44, 1913-20.

12. Gorka P, Kowalski ZM, Pietrzak P, Kotunia A, Kiljanczyk R, Flaga J, Holst J, Guilloteau P, Zabielski $\mathbf{R}$ (2009): Effect of sodium butyrate supplementation in milk replacer and starter diet on rumen development in calves. J Physiol Pharm, 60, 47-53.
13. Galip N (2006a): Effects of dietary Saccharomyces cerevisiae live yeast culture supplementation on ruminal digestion and protozoa count in rams fed with diets with low or high ratio forage/concentrate. Rev Med VetToulouse, 157, 609-13.

14. Galip N (2006b): Effect of supplemental yeast culture on ruminal protozoa and blood parameters in rams. Rev Med Vet-Toulouse, 157, 519-524.

15. Garcia CCG, Mendoza MGD, Gonzalez MS, Cobos PM, Ortega CME, Ramirez LR (2000): Effect of a yeast culture (Saccharomyces cerevisiae) and monensin on ruminal fermentation and digestion in sheep. Anim Feed Sci Tech, 83, 165-170.

16. Haddad G, Goussous SN (2005): Effect of yeast culture supplementation on nutrient intake, digestibility and growth performance of Awassi lambs. Anim. Feed Sci Tech, 118, 343-348.

17. Jinturkar AS, Gijar BV, Chauhan DS, Patil RA (2009): Effect of feeding probiotics on the growth performance and feed conversion efficiency in Goat. Indian J Anim Res, 43, 49-52.

18. Kamal R, Dutta T, Singha M, Kamrab DN, Patel M, Choudharyb LC, Agarwalb N, Kumarc S, Islama M (2013): Effect of live Saccharomyces cerevisiae (NCDC49) supplementation on growth performance and rumen fermentation pattern in local goat. J Appl Anim Res, 41, 285-288

19. Kawas JR, García-Castillo R, Garza-Cazares F, Fimbres-Durazo H, Olivares-Sáenz E, HernándezVidal G, Lu CD (2007): Effects of sodium bicarbonate and yeast on productive performance and carcass characteristics of light-weight lambs fed finishing diets. Small Rumin Res, 67,157-163.

20. Kosum N, Alcicek A, Taskin T, Onenc A (2003): Fattening performance and carcass characteristics of Saanen and Bornova male kids under an intensive management system. Czech J. Anim. Sci. 48, 379-386.

21. Mandebvu P, Galbraith H (1999): Effect of sodium bicarbonate supplementation and variation in the proportion of barley and sugar beet pulp on growth performance and rumen, blood and carcass characteristics in young entire lambs. Anim Feed Sci Technol, 82, 37-49.

22. Milewski S, Sobiech P (2009): Effects of dietary supplementation with saccharomyces cerevisiae dried yeast on milk yield, blood biochemical and hematological indices in ewes. Bull Vet Inst Pulawy, 53, 753-758.

23. Moolchand M, Wang J, Gui H, Shen Z (2013): Ruminal butyrate infusion increased papillae size and digesta weight but did not change liquid flow rate in the rumen of goats. J Anim Plant Sci, 23, 1516-1521.

24. Moya D, Calsamiglia S, Ferret A, Blanch M, Fandino JI, Castillejos L, Yoon I (2009): Effects of dietary changes and yeast culture (Saccharomyces cerevisiae) on rumen microbial fermentation of Holstein heifers. J Anim Sci, 87, 2874-2881.

25. Oetzel GR (2007) Subacute Ruminal Acidosis in Dairy Herds: Physiology, Pathophysiology, Milk Fat Responses, and Nutritional Management. http://www.vetmed.wisc.edu/ dms/fapm/fapmtools/2nutr/saral aabp.pdf (9 Aralık 2014)

26. Özsoy B, Yalçın S, Erdoğan Z, Cantekin Z, Aksu T (2013): Effects of dietary live yeast culture on fattening 
performance on some blood and rumen fluid parameters in goats. Rev Med Vet-Toulouse, 164, 263-271.

27. Papia N, Mostafa-Tehrania A, Amanloub H, Memarianb M (2011): Effects of dietary forage-toconcentrate ratios on performance and carcass characteristics of growing fat-tailed lambs. Anim Feed Sci Technol, 163, 93-98.

28. Titi HH, Dmour RO, Abdullah AY (2008): Growth performance and carcass characteristics of awassi lambs and shami goat kids fed yeast culture in their finishing diet. Anim Feed Sci Tech, 142, 33-43.

29. TSI (1991): Animal feeds-determination of metabolizable energy (Chemical method). TS9610. Turkish Standards Institution, Turkey, 2-3.

30. Weiss D. and Wardrop KJ (2010): Schalm's Veterinary Hematology. Willey-Blackwell, 6th Edition. 2121 State Avenue, Ames, Iowa 50014-8300, USA.
31. Yalçın S, Yalçın S, Can P, Gürdal AO, Bağcı C, Eltan Ö (2011): The Nutritive Value of Live Yeast Culture (Saccharomyces cerevisiae) and Its Effect on Milk Yield, Milk Composition and Some Blood Parameters of Dairy Cows. Asian Australas. J Anim Sci, 24, 1377-1385.

Geliş tarihi: 29.08.2014 / Kabul tarihi: 26.06.2015

\section{Address for correspondence:}

Assist Prof. Kadir Emre Buğdaycl,

Mehmet Akif Ersoy Üniversitesi,

Veteriner Fakültesi,

Hayvan Besleme ve Beslenme Hastalıkları Anabilim Dalı, İstiklal Yerleşkesi, 15030, Burdur, Turkey.

e-mail:kebugdayci@mehmetakif.edu.tr 